DOI: $10.19195 / 0137-1134.107 .4$

\title{
SOCIAL BENEFITS ONLY FOR SELECTED EU CITIZENS? AN OVERVIEW OF JUDGMENTS CONCERNING THE CITIZENSHIP OF THE EUROPEAN UNION AND ACCESS TO NATIONAL WELFARE BENEFITS TAKING INTO ACCOUNT THE LATEST RULINGS OF THE ECJ
}

\section{INTRODUCTION}

The idea of European identity is older than its legal acts and the European Union itself. Today, every citizen of a Member State of the EU is also its citizen, however few of them are aware that the privileges that come with this status are historically based on (pure) economic cooperation: the concept of EU citizenship and the related rights are a result of a long process of integration of the European community from a purely economically driven community towards the "citizens' Europe"1. This article gives an overview of the major breakthroughs during the development of the citizenship of the EU until 2013 as well as recent changes in this process since 2014, especially with regard to social rights. It discusses whether a social union can actually be proclaimed or if it has already come to an end.

\section{THE ROOTS OF THE CITIZENSHIP OF THE EUROPEAN UNION}

One of the first indications in legislation for a deeper cooperation and the development of the idea of a linked identity was described as a long-term goal in the preamble to the ECSC Treaty ${ }^{2}$ of 1951 as follows: "to establish, by creating an economic community, the foundation of a broad and independent community

1 J. Scholz, „Civis europaeus sum? — Der Unionsbürger und seine Heimat”, Öffentliches Recht 3, 2014, p. 1.

2 Treaty establishing the European Coal and Steel Community (Paris, 18 April 1951). 
among peoples"3. The Treaty of Rome ${ }^{4}$ signed in 1957 was - apart from the development of the economic issues - also focused on a closer union between the Member States ${ }^{5}$. The next step towards European citizenship was the landmark case of Van Gend \& $\operatorname{Loos}^{6}$ from 1963. Although the concept of "direct effect" was not mentioned in the EEC Treaty, the European Court of Justice ("ECJ") stated that the provisions of the EEC Treaty contain rights which can be claimed by individuals before national and European courts. In other words, the Court established that not only the Member States are subjects of the legal order of the Community, but also nationals of these states, hence its citizens ${ }^{7}$. These rights, which have been further specified by the ECJ in subsequent judgments, particularly include fundamental freedoms of the Common Market. Thus, the status of an individual has been essentially changed. However, an individual is entitled to invoke these rights only as a member of the Common Market. In consequence, fundamental freedoms, in particular the free movement of persons, were always tied to economic activity ${ }^{8}$. This led to the formation of a new term: the "Marktbürger", zen". Originally, market citizens had almost no active citizen-referred and political rights ${ }^{10}$ in the Member State in which they lived without having its nationality ${ }^{11}$. In 1968, Regulation (EEC) No 1612/68 ${ }^{12}$ came into force, which played an important role in the development of integration of migrant workers. Its main objective was to eliminate all obstacles to the mobility of workers ${ }^{13}$. The freedom of movement led to the foundation of a fundamental law for employees and their families. EU citizens had equal access to labour market in any Member State as citizens of that state, without particular permits, limits or other conditions ${ }^{14}$. Furthermore, this

${ }^{3}$ Cf. 5th recital in the preamble to the Treaty establishing the European Coal and Steel Community.

4 Treaty establishing the European Economic Community (Rome, 25 March 1957).

5 Cf. Art. 2 TEEC.

6 Judgment of 5 February 1963, Van Gend en Loos 26/62, EU:C:1963:1.

7 Judgment of 5 February 1963, Van Gend en Loos 26/62, EU:C:1963:1.

8 A. Hatje, “Art. 20 AEUV Rn. 2", [in:] J. Schwarze (ed.), EU-Kommentar, Baden-Baden 2012, p. 50.

9 Hans Peter Ipsen established the term "Marktbürger" as a description of the special legal relationship between EU-citizens, the Member States and the Community in 1963 at the FIDE Congress in The Hague; H.P. Ipsen, G. Nicolaysen, "Haager Kongreß für Europarecht und Bericht über die aktuelle Entwicklung des Gemeinschaftsrechts", Neue Juristische Wochenschrift 1964, p. 340.

${ }^{10}$ E.g. voting privileges and access to public service.

11 J. Scholz, op. cit., p. 1.

12 Regulation (EEC) No 1612/68 of the Council of 15 October 1968 on freedom of movement for workers within the Community repealed and replaced by Regulation (EU) No 492/2011 of the European Parliament and of the Council of 5 April 2011 on freedom of movement for workers within the Union Text with EEA relevance.

13 Cf. 5th recital to the Regulation (EEC) No 1612/68.

14 K. Heilbronner, "Verordnung Nr. 1612/68", [in:] M. Dauses (ed.), Handbuch des EU-Wirtschaftsrechts, Munich 2016, paragraph 5-10. 
citizen had the status of a "market citizen". This market-referred citizenship was still limited in its application. It did not contain much more than the right to choose the place of work within the Community ${ }^{15}$. Finally, in 1969, the Hague Summit of the EU ${ }^{16}$ led to the creation of an idea of European Citizenry. Since this intergovernmental conference initiatives have been taken with the goal of establishing the "Europe of Citizens" which supported the idea of European identity" ${ }^{17}$. The subsequent summit in Paris in 1974 asked a working group of the European Commission "to study the conditions and the timing under which citizens of the nine Member States could be given special rights as members of the Community"18. The Commission proposed the right to vote and stand as candidate at municipal elections ${ }^{19}$. The Tindemans Report of $1975^{20}$ suggested more political and social rights to the nationals of the Member States, such as equal access to public offices, gradual elimination of border controls and the establishment of a passport union, promotion of school and student exchange programmes, recognition of diplomas and better consumer protection ${ }^{21}$. In the following years, the only implemented rights of the "Europe for Citizens" were the universal suffrage for the European Parliament $^{22}$ and a passport of uniform pattern ${ }^{23}$.

In February 1984 the term "Citizenship of the European Union" appeared for the first time in Article 3 of the Draft Treaty Establishing the European Union, also known as the "Spinelli draft" 24 . Prior to that, the European Court of Justice

15 A.P. van der Mei, Free Movement of Persons within the European Community: Cross-border Access to Public Benefits, Oxford 2003, p. 43.

16 The Hague Summit, a conference of heads of state and government in The Hague on 1 and 2 December 1969, is actually a precursor of the European Council.

17 S. Kadelbach, "European Citizenship Rights", [in:] D. Ehlers (ed.), European Fundamental Rights and Freedoms, Berlin 2007, p. 543; J. Scholz, op. cit., p. 2.

18 Eighth General Report on the Activities of the European Communities in 1974, 1975, p. 297 (no. 11).

19 Bull EC 7/8-1975, 2508.

20 Report by Mr. Leo Tindemans - Prime Minister of Belgium - to the European Council. Bull EC, Supplement 1/76.

21 Bull EC, Supplement 1/76, p. 26; Y. Borgmann-Prebil, M. Ross, "The Principle of Equality and Citizenship of the Union”, [in:] H.J. Blanke, S. Mangiameli (eds.), The Treaty on European Union (TEU): A Commentary, Berlin 2013, p. 400.

22 Decision of the representatives of the Member States meeting in the council relating to the Act concerning the election of the representatives of the Assembly by direct universal suffrage, 76/787/ECSC, EEC, Euratom, OJ L 278, 8.10.1976, pp. 1-11 with amendments in the Council Decision of 25 June 2002 and 23 September 2002, 2002/772/EC, Euratom, OJ L 283, 21.10.2002, pp. 1-4.

23 Supplementary Resolution to the Resolution adopted on 23 June 1981 concerning the adoption of a passport of uniform pattern, of the Representatives of the Governments of the Member States of the European Communities, meeting within the Council on 30 June 1982, Official Journal of the European Communities, C 179, 16 July 1982, p. 1; S. Kadelbach, "Union Citizenship", Jean Monnet Working Paper 2003, p. 8.

24 Article 3: The citizens of the Member States shall ipso facto be citizens of the Union. Citizenship of the Union shall be dependent upon citizenship of a Member State; may not be independently 
confirmed in the case Luisi \& Carbone ${ }^{25}$ that the regulations regarding the free movement of services also guarantee a right to move to other Member States in order to receive services, particularly in respect of tourists, patients, business travellers and students ${ }^{26}$. This process included the gradual elimination of identity controls at national borders, which was finally specified explicitly in the first Schengen Agreement in 1985. A further step towards the European citizenship was the ERASMUS-Programme established in 1987. The Council Decision ${ }^{27}$ contained the term "People's Europe" for the first time in a secondary legislation.

The key element in the development of the Citizenship of the European Union was the guarantee of political rights, especially the freedom of movement, which consequently became independent of the existence of an employment contract. In order to establish an area of real freedom and mobility for all citizens of the Community, the Council adopted three directives ${ }^{28}$ concerning residence rights for persons with no occupational activity in 1990. Until 1992, the status of EU citizenship was not guaranteed by primary law. This changed with the Maastricht Treaty ${ }^{29}$ in November 1993. The citizenship of the European Union was formalized in Art. 17-21 EC, introducing new rights for citizens, particularly allowing them to have influence on the construction of the EU by means of political vote. Thus, the individual became an active and legitimate holder of rights and obligations of the European Union. While the main element of EU citizenship has always been the free movement of persons, it also included the right of settlement and employment within every Member State of the EU, as well as the right to vote and to be candidate for European and municipal elections in the Member State in which they reside, the right to diplomatic protection by other EU-States' embassies in a third country, in which the state of origin is not represented and the right to submit petitions to the European Parliament and to file complaints with the European Ombudsman.

acquired or forfeited. Citizens of the Union shall take part in the political life of the Union in the forms laid down by this Treaty, enjoy the rights granted to them by the legal system of the Union and be subject to its laws, OJ C 77, 19.3.1984, p. 36.

25 Judgment of 31 January 1984, Luisi and Carbone 286/82 \& 26/83, EU:C:1984:35.

26 A.P. van der Mei, op. cit., p. 51.

27 Council Decision of 15 June 1987 adopting the European Community Action Scheme for the Mobility of University Students (Erasmus), 87/327/EEC, OJ L 166, 25.06.1987, pp. 20-24.

28 Council Directive 90/365/EEC on the right of residence for employees and self-employed persons who have ceased their occupational activity, OJ L 180, 13.07.1990, p. 28; Council Directive 90/366/EEC on the right of residence for students, OJ L 180, 13.07.1990, p. 30; and Council Directive 90/364/EEC of 28 June 1990 on the right of residence (for nationals of Member States who do not enjoy this right under other provisions of Community law and for members of their families), OJ L 180, 13.07.1990, p. 26.

29 Treaty on European Union, signed at Maastricht on 7 February 1992, OJ C 191 of 29.7.1992. 
Initially, the European identity was often called a "pie in the sky"30, as it was considered an artificial idea with only symbolic character ${ }^{31}$, rather than a legally substantial institution ${ }^{32}$.

\section{EUROPEAN CASE LAW UNTIL 2014}

In view of the legal and political status of EU citizenship, it was up to the European courts to fill the "bloodless construct" 33 with life. But in the 1990s there was almost no judicial activity to consolidate the rights. This was probably due to the mere cause that the legal constellation was not brought up before the $\mathrm{ECJ}^{34}$.

After that phase of judicial minimalism ${ }^{35}$, the ECJ issued a line of landmark judgments (e.g. Sala ${ }^{36}$, Grzelczyk ${ }^{37}$, Baumbast ${ }^{38}$, Trojani ${ }^{39}$, Collins $^{40}$, Zhu Chen $^{41}$, Rottmann $^{42}$, Zambrano $^{43}$, Dereci ${ }^{44}$, Brey $^{45}$ ) strengthening the concept of EU citizenship and developing different aspects of social rights and of the right of residence.

In particular, the cases Sala, Grzelczyk and Baumbast extensively contributed in terms of outlining general principles and the legal sense of the concept of EU citizenship. In these cases, the Court took an individual-oriented approach and interpreted the concept of citizenship as a primary right with direct effect, meaning that every citizen is entitled to claim his rights directly on the basis of the provisions of the $\mathrm{ECT}^{46}$.

${ }^{30}$ H.U. Jessurun d'Oliveira, "Union Citizenship: Pie in the Sky?", [in:] A. Rosas, E. Antola (eds.), A Citizens' Europe: In Search of a New Order, Thousand Oaks 1995, p. 126.

31 D. Kostakopoulou, "European Union Citizenship: Writing the Future", European Law Journal 2007, p. 3.

32 L. Marácz, C. Versteegh, "European Citizenship as a New Concept for European Identity", Acta Universitatis Sapientiae, European and Regional Studies 1, 2010, no. 2, p. 166.

33 U. Haltern, Europarecht: Dogmatik im Kontext, Tübingen 2007, §10 paragraph 1255, pp. $599 \mathrm{ff}$.

34 J. Scholz, op. cit., p. 3.

35 D. Kostakopoulou, "When EU Citizens become Foreigners", European Law Journal 2014, p. 2.

36 Judgment of 12 May 1998, Sala C-85/96, EU:C:1998:217.

37 Judgment of 20 September 2001, Grzelczyk C-184/99, EU:C:2001:458.

38 Judgment of 17 September 2002, Baumbast and R C-413/99, EU:C:2002:493.

39 Judgment of 7 September 2004, Trojani C-456/02, EU:C:2004:488.

40 Judgment of 23 March 2004, Collins C-138/02, EU:C:2004:172.

41 Judgment of 19 October 2004, Zhu Chen C-200/02, EU:C:2004:639.

42 Judgment of 2 March 2010, Rottmann C-135/08, EU:C:2010:104.

43 Judgment of 8 March 2011, Ruiz Zambrano C-34/09, EU:C:2011:124.

44 Judgment of 15 November 2011, Dereci and Others C-256/11, EU:C:2011:734.

45 Judgment of 19 September 2013, Brey C140/12, EU:C:2013:565.

46 N.N. Shuibhne, "Limits Rising, Duties Ascending: The Changing Legal Shape of Union Citizenship", Common Market Law Review 2015, p. 896. 
In Sala, the ECJ ruled on the situation of a long-term unemployed migrant worker from Spain whose claim for child allowance in Germany had been rejected. The ECJ concluded that any national of a Member State is protected against discrimination on the grounds of nationality by another Member State due to his European Citizenship.

In the significant case Grzelczyk, the Court decided that students residing in a Member State other than their own have to obtain a minimum subsistence allowance on similar conditions as the nationals of the host state. The ECJ specified its interpretation of the interactions between Art. 18 and Art. 21 TFEU, which were only indicated in previous decisions. Unlike in the case of Bickel and Franz ${ }^{47}$, the plaintiff was not in a situation to invoke a fundamental freedom in the main proceedings. Moreover, he could not base his claim on the right of residence, as in the Sala case. Nevertheless, the ECJ declared in the first place that the provisions of the Treaty were applicable in view of Art. 18 para. 1 TFEU. (ex. Art. 12 para. 1 EC). As to the substance matter, the ECJ based its argumentation on Art. 21 para. 1 TFEU (ex. Art. 18 para. 1 EC) - the citizenship regulation - and considered for the first time that this provision confers on European citizens the right to move and reside within the territory of the Member States. Moreover, the status of a citizen of the European Union was declared to be the fundamental status of nationals of all the Member States, allowing them to enjoy the same treatment in law irrespective of their nationality within the EU ${ }^{48}$.

In the Grzelczyk case, the relevant issue concerned the right to social benefits. Therefore, it was still unclear whether the ECJ recognizes the direct applicability of Art. 21 para. 1 TFEU.

Finally, the Court confirmed the direct applicability of Art. 21 para. 1 TFEU in the case Baumbast. However, in this judgment the ECJ also emphasized the legitimacy of secondary legal restrictions of the right of residence (the proof of sufficient resources and health insurance) and underlined the limits of application of these restrictions. This includes in particular the principle of proportionality.

The general principles formulated in the essential cases Sala, Grzelczyk and Baumbast have been applied in the consecutive judgments of the ECJ. Subsequently, the Court has further specified the legal content of EU citizenship. Based on the principle evolved in Baumbast, the ECJ decided in the Trojani case that an economically inactive EU citizen living in a host Member State is entitled to claim social assistance benefits on equal conditions as the nationals of that Member State. Despite the lack of sufficient resources (as required by Directive 90/364), the plaintiff is entitled to claim his right by direct application of the provision of the Treaty on Union citizenship under the condition of a certain period of residence or if a residence permission has already been granted ${ }^{49}$. The Court based its

47 Judgment of 24 November 1998, Bickel and Franz C-274/96, EU:C:1998:563.

48 Judgment of 20 September 2001, Grzelczyk C-184/99, EU:C:2001:458, paragraph 31.

49 Judgment of 7 September 2004, Trojani C-456/02, EU:C:2004:488, paragraph 43. 
judgment on the right of free movement for citizens of the EU (Art. 21 TFEU, ex. Art. $18 \mathrm{EC}$ ), which is determined by the principle of non-discrimination provided in Art. 18 TFEU (ex. 12 EC). To summarize, the Court elaborated the following formula: if a citizen of the EU makes use of his right of free movement by going to another Member State and staying there lawfully, he is protected by the principle of general prohibition of discrimination in Art. $12 \mathrm{EC}^{50}$.

The dogmatic structure of the judgment in the Bidar case is clearly linked to the Court's statement in Grzelczyk. The ECJ confirmed once again that the student's right to reside in the host Member State is originally stipulated in Art. 21 TFEU and consequently the student enjoys the right to equal treatment under Art. 18 TFEU. For this reason, financial support can be claimed on the same grounds as in the case of nationals, provided that a certain degree of integration in the society of that Member State is proven ${ }^{51}$.

The aforementioned judgments outlined that EU citizenship was not automatically linked to the market economy of the Union. The ECJ clearly considers that a citizen of a Member State enjoys rights equal to those of any national citizen, due to the mere fact of their EU citizen status ${ }^{52}$. As such, the right to non-discrimination provided in Art. 18 TFEU (ex. 12 EC) can be claimed by every citizen of the European Union. The judgments were influenced by the principle of social and financial solidarity between the Member States to supply minimal financial aid to non-national EU citizens. Considering these judgments, the Court can in fact be perceived as the driving force for integration of the $\mathrm{EU}^{53}$.

In line with the historical and political process within the EU, the ECJ developed a new legal structure of the European citizenship, based on the "human capital" and resulting in a fully-fledged "citizen of Europe" 54 .

\section{ECJ JUDGMENTS SINCE 2014}

In 2014, the nature of judgments changed noticeably. The latest judgments concerning the citizenship of the EU and the access to national welfare benefits in the cases of Dano ${ }^{55}$ Alimanovic $^{56}$, Garcia-Nieto $^{57}$ and Commission v United

50 J. Scholz, op. cit., p. 5.

51 Judgment of 15 March 2005, Bidar C-209/03, EU:C:2005:169, paragraph 59, 63.

52 Judgment of 17 September 2002, Baumbast and R C-413/99, EU:C:2002:493, paragraph 83.

53 J. Scholz, op. cit., p. 9.

54 A.J. Menéndez, "European Citizenship after Martinez Sala and Baumbast. Has European Law Become More Human but Less Social?", [in:] M.P. Maduro, L. Azoulai (eds.), The Past and Future of EU Law, Oxford and Portland 2010, p. 363.

55 Judgment of 11 November 2014, Dano C-333/13, EU:C:2014:2358.

56 Judgment of 15 September 2015, Alimanovic C-67/14, EU:C:2015:597.

57 Judgment of 25 February 2016, García-Nieto and Others C-299/14, EU:C:2016:114. 
Kingdom ${ }^{58}$ have become landmark decisions for the contemporary understanding of EU citizenship. The main question of these cases is whether or not economically inactive EU citizens should be entitled to certain social benefits from other Member States. The first three cases originate from Germany. Each of them refers to the German non-contributory social benefit "Arbeitslosengeld II", also known as "Hartz IV". The last judgment from June 2016 regards British legislation, specifically social benefits - including family benefits, such as child benefit and child tax credit $^{59}$.

In 2014, the Court of Justice had to decide by way of preliminary ruling whether economically inactive EU citizens who move to another Member State only in order to obtain social benefits may be excluded therefrom.

In the particular case, the ECJ dealt with the situation of Elisabeta Dano, a 25-year-old unemployed woman from Romania, as well as her five-year-old son, who had been residing in Germany since November 2010, where they lived at Ms Dano's sister's place, who provided for them. Ms Dano received child benefit and maintenance payments of 317 euros per month from the German State for her son. The Romanian applied for benefits according to Hartz IV-law, on the basis of a provision allowing jobseekers to claim benefits, although she was not looking for employment and although she did not enter Germany in order to seek work. After the job centre in Leipzig refused to grant her benefits, she filed a claim with the German Social Court. That Court referred the case to the ECJ to clarify whether the refusal of benefits is compatible with the EU law and asked in particular if Member States are precluded by Art. 18 TFEU and Art. 20 TFEU and Art. 24(2) of Directive 2004/38/EC, in order to prevent an unreasonable recourse to non-contributory social security benefits under Art. 70 of Regulation No 883/2004 which guarantee a level of subsistence, from excluding EU citizens in need from accessing those benefits in full or in part, which would have otherwise been provided to own nationals in the same situation ${ }^{60}$.

The Court decided that for the purpose of having access to certain social benefits, nationals of other Member States can claim the same treatment as nationals of the host Member State only if their residence fulfils the conditions of the Citizens Rights Directive 2004/38/EC ${ }^{61}$. For the period of residence between three months and five years, one of the conditions of Art. 7 of the Directive for a right of residence is that economically inactive persons must possess sufficient

58 Judgment of 14 June 2016, Commission v United Kingdom C-308/14, EU:C:2016:436.

59 Judgment of 14 June 2016, Commission v United Kingdom C-308/14, EU:C:2016:436.

60 Judgment of 11 November 2014, Dano C-333/13, EU:C:2014:2358, paragraph 45.

61 Directive 2004/38/EC of the European Parliament and of the Council of 29 April 2004 on the right of citizens of the Union and their family members to move and reside freely within the territory of the Member States, OJ L 158, 30.4.2004, pp. 77-123, amending Regulation (EEC) No 1612/68 and repealing Directives 64/221/EEC, 68/360/EEC, 72/194/EEC, 73/148/EEC, 75/34/EEC, 75/35/ EEC, 90/364/EEC, 90/365/EEC and 93/96/EEC. 
resources of their own ${ }^{62}$. Thus, the Court emphasized that the Directive intends to stop economically inactive EU citizens who exercise their right of freedom of movement solely in order to make use of the host Member State's welfare system to fund their livelihood ${ }^{63}$. Therefore, each individual case should be examined specifically, without taking account of the social benefits claimed, in order to determine whether it fulfils the condition of having sufficient resources to qualify for a right of residence under Art. 7(1)(b) of Directive 2004/3864.

Ms Dano and her son did not have sufficient resources, therefore the Court confirmed they cannot claim a right of residence in Germany under the Directive on free movement of EU citizens. Thus, they cannot invoke the principle of non-discrimination either under Art. 24(1) of the Directive or under Art. 4 of the Regulation No 883/2004 on the coordination of social security systems ${ }^{65}$.

In Alimanovic and Garcia-Nieto the Court confirmed its findings from the Dano case. In the first case, the ECJ decided that a Member State may reject certain non-contributory social security benefits to EU citizens who move to that State to find work. In particular, EU citizens who arrive in Germany in order to receive social assistance or whose right of residence arises only from their search for employment are excluded from the entitlement to German "Arbeitslosengeld II" benefits. The second case confirms the last two recent judgments and implies that a Member State may exclude nationals of other Member States from certain social benefits, particularly social assistance similar to the German "Arbeitslosengeld II", during the first three months of residence.

Finally, the Court continued its recent case law ${ }^{66}$ with the findings in the C-308/14 case Commission v United Kingdom, although it did not address particular non-contributory cash benefits as in Dano etc. ${ }^{67}$ The subject matter of the infringement proceedings were the conditions of entitlement to family benefits such as child benefit and child tax credit. The ECJ decided that also in case of applications for family benefits, Member States may introduce the requirement of lawful residence in their national social legislation. Consequently, the United Kingdom can oblige recipients of child benefit and child tax credit to have a title to reside. Although that condition constitutes an indirect discrimination based on

62 Judgment of 11 November 2014, Dano C-333/13, EU:C:2014:2358, paragraph 77.

63 Judgment of 11 November 2014, Dano C-333/13, EU:C:2014:2358, paragraph 78.

64 Judgment of 11 November 2014, Dano C-333/13, EU:C:2014:2358, paragraph 80.

65 Regulation (EC) No 883/2004 of the European Parliament and of the Council of 29 April 2004 on the coordination of social security systems, OJ L 200, 7.6.2004, pp. 1-49.

66 Judgment of 19 September 2013, Brey C140/12, EU:C:2013:565; Judgment of 11 November 2014, Dano C-333/13, EU:C:2014:2358; Judgment of 15 September 2015, Alimanovic C-67/14, EU:C:2015:597; Judgment of 25 February 2016, Garcia-Nieto and Others C-299/14, EU:C:2016:114.

67 Judgment of 11 November 2014, Dano C-333/13, EU:C:2014:2358; Judgment of 15 September 2015, Alimanovic C-67/14, EU:C:2015:597; Judgment of 25 February 2016, García-Nieto and Others C-299/14, EU:C:2016:114. 
Art. 4 of Regulation (EC) 883/2004, it is justified by the need to protect the finances of the host Member State.

Since 2014, significant differences have arisen in the approach of the ECJ as to the legal findings in contrast to its judgments before that date.

Interestingly, the Court in Dano initially mentions the guiding principle constituted in Grzelczyk, i.e. that the status of a citizen of the Union is destined to be the fundamental status of nationals of the Member States ${ }^{68}$, but consequently decides to base its judgment exclusively on the interpretation of Directive 2004/883 with no regard to the general principles of the citizenship and non-discrimination regulated in Art. 18 and Art. 21 TFEU ${ }^{69}$. The judgments in Alimanovic and García-Nieto follow a similar approach ${ }^{70}$. In contrast, the judgments before 2014 were regularly construed to include considerations on secondary legislation and the general principles of EU citizenship defined by the Treaty provisions. Also in $B r e y^{71}$ the Court emphasizes the importance of fundamental principles of EU law and clarifies that the right to freedom of movement is the general rule, whereas the conditions laid down in Directive 2004/38 should be "construed [only] narrowly" considering the limits laid down by EU law and the principle of proportionality.

Moreover, the Court bases its argumentation in Dano, Alimanovic and García-Nieto ${ }^{72}$ on the objective of Directive 2004/38, set out in recital 10 in its preamble, namely preventing the Union citizens who are nationals of other Member States from becoming an unreasonable burden on the social assistance system of the host Member State, while in Brey the ECJ held that the general "aim of Directive [...] is to facilitate and strengthen the exercise of the primary and individual right conferred directly on all Union citizens by the Treaty - to move and reside freely within the territory of the Member States" ${ }^{73}$. In addition, the Court refers again to the principle of financial solidarity between the Member States ${ }^{74}$.

Similarly in Grzelczyk the Court mentions the sixth recital in the Directive ${ }^{75}$ preamble, which implies that beneficiaries of the right of residence must not become an unreasonable burden on the public finances of the host Member State, but it

68 Judgment of 11 November 2014, Dano C-333/13, EU:C:2014:2358, paragraph 58; Judgment of 20 September 2001, Grzelczyk C-184/99, EU:C:2001:458, paragraph 31.

69 Judgment of 11 November 2014, Dano C-333/13, EU:C:2014:2358, paragraph 62.

70 Judgment of 15 September 2015, Alimanovic C-67/14, EU:C:2015:597, paragraph 47; Judgment of 25 February 2016, Garcia-Nieto and Others C-299/14, EU:C:2016:114, paragraph 54.

71 Judgment of 19 September 2013, Brey C140/12, EU:C:2013:565, paragraph 70.

72 Judgment of 11 November 2014, Dano C-333/13, EU:C:2014:2358, paragraph 74 ; Judgment of 15 September 2015, Alimanovic C-67/14, EU:C:2015:597, paragraph 50; Judgment of 25 February 2016, Garcia-Nieto and Others C-299/14, EU:C:2016:114, paragraph 39.

73 Judgment of 19 September 2013, Brey C140/12, EU:C:2013:565, paragraph 53.

74 Judgment of 19 September 2013, Brey C140/12, EU:C:2013:565, paragraph 72.

75 Council Directive 93/96/EEC of 29 October 1993 on the right of residence for students, OJ L 317, 18.12.1993, pp. 59-60. 
principally focuses the argumentation on "a certain degree of financial solidarity between nationals of a host Member State and nationals of other Member States"76.

These examples show that the ECJ has deviated from its long-standing jurisprudence and chooses different explanations to justify its dissimilar judgments, which apparently depend on the current situation in the EU and the political will of the Member States. The fear of the so-called benefit tourism as well as losing the United Kingdom as a Member State of the European Union may have influenced the Court's judgment.

In consequence, the aforementioned recent jurisprudence, in which the principle of equal treatment and the interest of the Member States to protect their social systems come in conflict, contributes to a state of certain hopelessness for the people who intend to make use of a "non-economic" freedom of movement. The entitlement to these social benefits corresponds to the right of residence. If the right of residence exists, the principle of equal treatment should be principally observed. Consequently, as far as the affected person secures sufficient resources, they do not need additional social benefits from the host Member State. In the opposite case, they have no right of residence and therefore they are not entitled to obtain non-contributory social security benefits. Thus, in the judgment of Dano it comes to an internal paradox. The Court grants the right to equal treatment in access to social benefits only to persons who have their own means of livelihood -i.e. persons who would not apply for social benefits. Such a structure essentially prevents the implementation of the right to social benefits, and, which seems even more staggering, it differentiates the situation of particular citizens of the European Union. As a result of such a situation, the institution of citizenship is on the way to lose its relevance.

In consequence, the current judgments lead to an impasse for underprivileged people, regardless whether they are searching for work. This is shown particularly in the Alimanovic case, which can be perceived as a judgment even stricter than Dano, mainly due to its central message, which is that job search does not protect from the exclusion of non-contributory social security benefits.

\section{CONCLUSION}

Through its latest four strict judgments ${ }^{77}$, the ECJ points out that the heyday of a benefit-oriented social citizenship is behind us. The message the ECJ intends to convey in its rulings is clear: EU citizenship depends in fact on the participation

76 Judgment of 20 September 2001, Grzelczyk C-184/99, EU:C:2001:458, paragraph 44.

77 Judgment of 11 November 2014, Dano C-333/13, EU:C:2014:2358; Judgment of 15 September 2015, Alimanovic C-67/14, EU:C:2015:597; Judgment of 25 February 2016, García-Nieto and Others C-299/14, EU:C:2016:114; Judgment of 14 June 2016, Commission v United Kingdom C-308/14, EU:C:2016:436. 
of an individual in the market economy and economically inactive EU citizens cannot profit from the same rights as those who are economically active. Does this mean they are de facto non-citizens? Are we back to the times, when the position of a "market citizen" was emphasized? If so, what may have caused this paradigm shift in the case law of the ECJ concerning EU citizenship and social rights? Interestingly, the rigorous argumentation in the judgments appeared shortly after the EU opened its doors to Romanian and Bulgarian workers. At the beginning of 2014, Romanians and Bulgarians received a full right to work freely across the Union. The change has prompted fears of mass migration or social tourism, particularly in Germany and Britain. In fact, the aforementioned rulings of the ECJ actually prevent foreign EU citizens from becoming an unreasonable burden for the Member States' social assistance system; they also protect the States from social tourism. Regarding this, the Court determines in the Garcia-Nieto case that an individual claim would not become an "unreasonable burden" for the national system of social assistance, "but the accumulation of all the individual claims which might be submitted to it would be bound to do so"78. Is this kind of judgment enough to convince the eurosceptics? Based on the example of Brexit and the previously given judgment in the Commission v United Kingdom case I very much doubt that.

Coming to a conclusion, it can be noticed, on the one hand, that politics may have well influenced the Court's judgments - which certainly is not the way a court of law should function. On the other hand, some Member States could find themselves flooded by social migrants, whose movement is motivated solely by the intention to profit from foreign welfare systems. As long as the ECJ follows this rigorous rule while taking into account the principle of proportionality, the interests of all concerned should remain balanced. The Court is consequently reinforcing the guideline that EU law does not intend to create a common social security system with unlimited access for its every citizen, but aims to ensure a maximum level of market-oriented coexistence between the Member States.

Answering the main question of this article, it should be said that the Court in fact differentiates between EU citizens, particularly the poor and the rich or the working and the unemployed. It can be seen as a step backwards on the road to further integration of the Old Continent and as a division of EU citizens into those "equal" and "more equal". One thing is certain; the recent judgments recalled the roots of the EU as primarily an economic union. It is a prime example that the legal relevance of EU citizenship cannot extend further than the political will of the Member States and their societies. In the present challenging times there might be no other way to arrange a balance between the stance of the national governments and the compliance of the EU citizenship.

78 Judgment of 25 February 2016, García-Nieto and Others C-299/14, EU:C:2016:114, paragraph 50 . 


\section{ŚWIADCZENIA SOCJALNE TYLKO DLA WYBRANYCH OBYWATELI UE? PRZEGLĄD ORZECZEŃ DOTYCZĄCYCH OBYWATELSTWA UNII EUROPEJSKIEJ ORAZ DOSTĘU DO KRAJOWYCH ŚWIADCZEŃ Z ZAKRESU POMOCY SPOŁECZNEJ Z UWZGLĘDNIENIEM NAJNOWSZYCH WYROKÓW TRYBUNAŁU SPRAWIEDLIWOŚCI}

\section{Streszczenie}

Niniejszy artykuł obejmuje przegląd przełomowych momentów w trakcie rozwoju obywatelstwa Unii Europejskiej do roku 2013, a także ostatnich zmian w tym procesie od 2014 roku, zwłaszcza w odniesieniu do praw socjalnych. Pierwsza część artykułu skupia się na korzeniach obywatelstwa UE oraz przełomowym w tej dziedzinie orzecznictwie, m.in. dotyczącym spraw Sala, Grzelczyk oraz Baumbast. Następnie — w drugiej jego części — autorka, przedstawiając najnowsze orzecznictwo TSUE dotyczące współczesnego rozumienia obywatelstwa w sprawach Dano, Alimanovic, García-Nieto oraz Komisja/Zjednoczone Królestwo, rozważa zasadność określenia Unii Europejskiej mianem ,unii socjalnej” oraz podejmuje dyskusję, czy unia ta wraz z najnowszym orzecznictwem dobiegła końca. 